\author{
Kamila Rezmer-Płotka \\ Nicolaus Copernicus University, Poland \\ ORCID: https://orcid.org/0000-0002-1458-5076 \\ e-mail: kamila.rezmer@onet.pl
}

\title{
Theological Anthropology of the Contemporary Polish Candidate for Altars
}

Book review: Ryszard Ficek, Christians in socio-political life. An Applied Analysis of the Theological Anthropology of Cardinal Stefan Wyszyński, Primate of Poland, Adam Marszałek Publishing House, Torun 2020, pp. 406

Every year, millions of Catholics around the world gain a new official blessed or saint, who is formally approved by the Catholic Church, and thus can be the object of universal religious worship. The path to the altar is not straightforward, despite the many prerequisites that must be met in the best situation, there are martyrs (Rezmer, 2018, pp. 171-184). Giving life for faith is often the first and important step on the path to process of beatification and then canonization. In a completely different situation there are people who were not martyrs, but met many other premises and were surrounded by spontaneous worship by a local community. A good example is Saint John Paul II, and soon blessed Primate of Poland, Stefan Wyszyński, whose miracle [confirmed miracle is a prerequisite for recognition of the candidate - K.R.P.] was approved by Pope Francis (Kard. Wyszyński wkrótce..., 2019). The more important are publications such as "Christians in socio-political life. An Applied Analysis of the Theological Anthropology of Cardinal Stefan Wyszyński, Primate of Poland" by Ryszard Ficek, which bring closer the profiles of such people, describe their life or teaching. Thanks to them, a wider audience has the opportunity to meet people distinguished for the Catholic Church.

The monograph consists of an introduction, four substantive chapters and a summary chapter, in addition, the publication has an index of abbreviations used in the publication. The first chapter is, above all, an explanation of the personalistic concept of man, which is the basis for Wyszyński's teaching and personal rights, which are at the top at his hierarchy (p. 87). There are also references to family and nation which are key social elements life, 
which is proper to the social thought of the Church. The author also indicates the reasons for the unwillingness of the primate to state structures and outlines the situational context. The second chapter is a smooth transition to the issue of Christian activity in the socio-political and economic dimension. It is at these levels that human dignity and primacy in the reality of the temporal world is to be fully realized (pp. 171-172). The third, very extensive chapter is an attempt to reconstruct the category of the nation's responsibility for the state based on Wyszyński's statements. The difficult history of the Polish nation was also outlined, which probably had a great significance for the teaching of the Primate of Poland. Especially the period before the political transformation, which was a difficult lesson for the society and the Catholic Church. The last substantive chapter is a presentation of a personalist vision of social life rooted in the doctrine and teaching of the Church. In this case, Christian values are the foundation for realizing the idea of the common good and conditions for creating socio-political order (p. 334) based on values such as love (p. 341), justice (p. 343), truth (p. 347), freedom (p.347) and peace (p. 352).

Unfortunately, the publication is not without weaknesses. What was lacking was the preparation and description of the research tool that would allow conducting an analysis of source in a consistent and objective manner. The author also undertook a very difficult task, which is to determine the impact of the social and political situation on the teaching of the Primate. In this case, it is impossible to assess to what extent it was dominated by the conditions and the situational context. One can get the impression that the publication also attempts to justify some aspects of teaching by referring to history, which seems controversial to people living after 1989. Although it must be admitted that part of Stefan Wyszyński's ideas are anchored and consistent with the social teaching of the Catholic Church. It is important, that the author is aware of the restrictions of publication. The publication's strong point is, above all, the numerous sources used, which allow for reliable reconstruction of the teaching of the Primate of Poland. Thus, the publication stands out from other items dealing with similar issues. The author showed an impressive knowledge of the subject, and bibliographic entries indicate the enormous effort and hard work put into reproducing the Catholic social teaching in the edition of Cardinal Stefan Wyszyński. In the reviewed publication, an analysis was easily carried out to understand the phenomenon of socio-political thought oriented towards human person during a difficult period in the history of Poland. The substantive chapters also show the author's concern for the most accurate possible explanation of the concepts, references to facts and an attempt to explore the studied subject in the best possible way. A great advantage of the publication are the author's efforts to reconstruct the teaching features of the Primate of Poland, which can be used for further research.

Ryszard Ficek's book is a very valuable position on the publishing market and highly recommendable. It will interest both theologians and people interested in the character of Stefan Wyszyński, but it will certainly also be appreciated by political scientists and sociologists. 


\section{References:}

Kard. Wyszyński wkrótce błogosławiony, papież zatwierdził cud, https://www.vaticannews.va/pl/papiez/ news/2019-10/kard-wyszynski-wkrotce-blogoslawiony-papiez-zatwierdzil-cud.html, [Accessed 2 May 2020].

Rezmer, K. (2018), „Od ofiary do chwały - czyli ofiary zbrodni wynoszone na ołtarze”. In K. Amrozy \& N. Gburzyńska (Eds.), Oblicza bezpieczeństwa we współczesnym świecie (171-184). Toruń: Adam Marszałek Publishing House. 